\title{
The Influence of Political Marketing Communication Jokowi on Facebook Towards the Image and Reputation among Millennial Generation in General Election 2019
}

\author{
Steffi $^{1}$, Nur Kholisoh ${ }^{2}$ \\ \{steffi.angkasa@gmail.com¹, nur.kholisoh@mercubuana.ac.id² \\ Universitas Mercu Buana, Jakarta, Indonesia ${ }^{12}$
}

\begin{abstract}
In Indonesia's current political situation, political marketing has an essential role in winning the general election. In an open competition, among candidates, Presidents and Vice Presidents strive maximally to give information so that the voters will be in favor of them. This situation also dealt with the same to Joko Widodo, who was a candidate for President in General Election 2019 by performing political marketing communication through various media such as new media as a communication message tool, particularly among the millennial generation. This research aimed to examine and measure the influence of Joko Widodo's political information on Facebook towards the image and reputation among the millennial generation in the last 2019 General Election. This research uses the Stimulus Organism Response theory, a theory of political marketing communication, and a theory about image and reputation. This research also uses a positivist paradigm with a qualitative approach. The method used is a survey method using questionnaires to obtain information from millennial generation in Jakarta, with a total 400 people. The sampling technique uses proportional sampling and data analysis with path analysis. This research shows that political marketing communication has only $9.6 \%$ of a direct impact on reputation. The image has an immediate effect on a reputation as much as $86,6 \%$, while the indirect impact of political marketing communication of image towards reputation is $64,49 \%$.
\end{abstract}

Keywords: Political Marketing Communication, Facebook, Image, Reputation, Millennial

\section{Introduction}

In current Indonesia's political situation, particularly when contestation vote for President and Vice President of Republic Indonesia 2019, political marketing holds an essential role in the context of democratization which is actualized through marketing strategies as the fittest way to earn the victory in General Election [1]. Marketing, adapted into the political world, can be used to increase the efficiency and effectiveness of ideological transfer and work programs from candidates to society. Moreover, marketing can inspire how the candidates create a product of issues and work programs based on problems that society currently faces. The field "political marketing", although relatively new, has grown quickly over the last decade [2]. Political marketing gives considerable contributions to the candidates of general 
election, especially to the campaign executors. The term "Political marketing" includes these activities made by political parties to affect voters and is focused on influencing the individuals regarding political candidates to reach the maximum number of vote [2].

In an open competition between pairs candidates for President and Vice President, they will strive optimally in spreading information so that the voters will be in favor of them. Besides, to win a general election, then candidates must do everything to make the voters give their voice for them. Political marketing also works on Joko Widodo, a candidate of Indonesian President in 2019, who has undergone political marketing communication through various media, including the new media.

Today, there are many candidates and political parties who use the new media, namely the internet, as the channel of their political communication [3]. In the presidential election in 2014 social medias supported Jokowi's campaign. All the activities of Jokowi were described in these social media [4]. The data from the 2015 U.K. general election generally find little evidence of the involvement of social media communications in empowering campaign supporters [5]. According to Nielsen, in the second quartile in 2015, Indonesia was positioned in 8th place of 3,2 billion internet users worldwide (Internetworldstats in Monggilo [6]).

For the young generation, the internet is a dominant public place. The Indonesian Internet Service Provider Association (APJII) mentions that millennial generation being the most internet users, who aged between 16-18 years old as much as 16,68\%, and 19-34 years old $49,52 \%$. According to APJJI, $87,13 \%$ of millennials open social media channels such as Facebook, Instagram, Twitter, and YouTube. Social media has enabled exchange value production of election information by turning election-related information into marketable commodity in election campaigns [7]-[9]. These trends would not have emerged without the political and media industry transformations that date back to 1998 that have privileged the importance of 'identity politics' through direct election, competing multi-party systems and a new pluralism of expression that has come about by the revocation of media restrictions [10]. This is important considering that one of the targets of the political campaign is millennial generation, who have a fairly high level of media literacy [11], [12].

Millennial generation becomes a potential group for political parties to earn more significant support. The number of millennials who are young voters keeps increasing in each general election. In 2010 the young generation in total were 40.7 million people, while in 2014, the General Election Commission (KPU) mentioned that the number of young voters increased to 59.6 million. Meanwhile, in 2019 the number of young voters was approximately 60 million people from all over Indonesia. Considering the number of young voters as millennial generation very potential to earn reinforcement, therefore many political parties attempt to deliver their political message through media that is mostly used by youngsters, a new media. Through the new media, it is hoped that the political messages conveyed can be more widely accepted and understood by the millennial generation who are the most extensive internet users today.

\subsection{S-O-R Theory (Stimulus Organism Response)}

This research uses the S-O-R theory (Stimulus Organism Response) conducted by Hovland et al. [13] in 1953. The underlying assumption of this S-O-R theory is that the cause of behavioral change depends on stimulus quality accepted by organisms. In this research, what we call stimuli is the message in political marketing communication delivered on Facebook. The millennial generation receives this message as the message recipient (organism). In this case, the organism can accept or reject the message given by the sender. If 
it is rejected, meaning that the stimuli are less efficient to influence millennial generation. In contrast, if stimuli are accepted, then the message is considered works for them by gaining their attention.

\subsection{Political Marketing Communication}

One of the political marketing models sold well in today's political contestation is the Lees-Marshment Model [14]. This model, also known as Comprehensive Political Marketing (CMP). CMP is not only centered on the parties' way and strategy in campaigning but, in a broader context, is how the party designs its policy or organization so that the market will demand. This model focused on what was undergone by the parties in responding to the market's demand (voters). The marketing concepts and techniques are not only for public parties to communicate the product and how the parties should determine what to be their products, and how they should behave on the political market. There are many characteristics of the CMP model, namely, implementing the marketing approach to all parties organization's behavior, integrating political science in analysis and marketing concepts used to adjust with a traditional understanding of political parties, and highlight Product Oriented Party (POP), Sales Oriented Party (SOP), and Market Oriented Party (MOP)

Product Oriented
Party (POP)
- Oriented on
products. Party or
candidate already
has products
(regulations,
candidates, work
programs, etc.) and
promote their
products in order to
convince the voters.

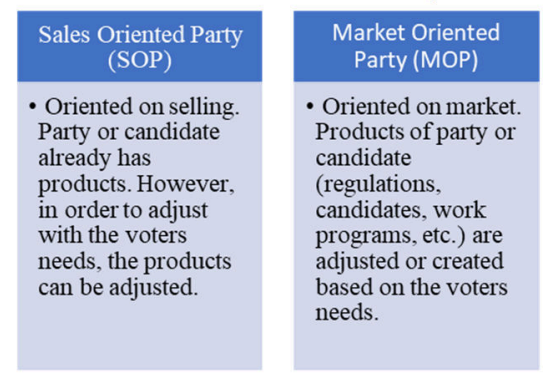

Fig 1. Political Marketing Lees-Marshment Model

\subsection{New Media}

New media is a term used for all communication media, which has a background in communication and information technology. New media include the emergence of digital, computer, or information and communication technology. Today, the internet as a new media communication tool becomes the needs of most people because it has fast access in sending or receiving data, giving information from other hemispheres, and can communicate between a human to another even if they stand in the different territory. Meanwhile, social media is an online media where users can communicate and interact with each other. According to Feri Sulianta [15], the types of social media are Facebook, Twitter, YouTube, and Instagram. The survey result conducted by CSIS (2017) found that $81,7 \%$ of millennials have Facebook, $70,3 \%$ have WhatsApp, and $54,7 \%$ have Instagram.

Based on this data, what was meant as a new media in this research is social media Facebook which was firstly invented in 2004 by Mark Zuckerberg as the founder. Facebook has become the most prominent social media networking today with many benefits that can be utilized, such as a place to look for friends, a place for promotions, a place for discussions, a place for build relationship, and a place for learning and entertaining. Social media platforms such as Facebook have a dramatically different structure than previous media technologies [16]. In recent years, Facebook has become a regular part of political campaigning as such a subject of an extensive research [17]. 


\subsection{Reputation}

Reputation is an intangible asset that is difficult to measure and to describe its existence since its reputation is not a product that can be seen. However, a good reputation can reinforce the company's position when in a battle with their rivals. Fombrun in Rani Sherly Fajrina [18] mentioned that reputation is a form of someone's experience with a product or service they have undergone. A good reputation will boost credibility, make consumers more confident because they will get what has been promised to them. Reputation becomes one of the warranties that the consumers will get will be the same as their expectations.

\subsection{Image}

The political leader's image is a dimension that connects the voters and the politician. The brand personality of the political leader can be used to better understand the nature of impression management [19]. Self-identification with a candidate can be said to be a human feeling that a politician is a voters' political identity. In other words, someone will identify themselves as a part of a specific political leader or feel so close to their political leader [20]. 'Brand personality' represents an increasing emphasis on the non-tangible, brand-oriented dimensions of products - political product [19]. The image of the political leader also can be seen from intermediation by voters on how far a political leader has its ability to bridge the voters' interest with the public decisions which can be made as regulations in parliament or a government's decree. If this evaluation is mostly negative, then the intermediation function is less effective, and vice versa.

\subsection{Millennial Generation}

Kupperschmidt [21] mentioned that generation is a group of individuals who identify themselves based on the similarity of birth year, age, location, and occurrences in their life, which has a significant impact on their phase of growth. Howe \& Strauss [22], [23] divided generation according to the similarity time of birth and similarity of historical occurrence. Today, millennial generation becomes a trending topic in society, starting from educational, technology, norms, and cultural aspects. The writers, William Strauss and Neil Howe [22], where broadly known as the pioneers of creating the "millennial" term. A millennial generation or sometimes also named as Y generation is a group of people who were born after X generation, people who were born during 1980- 2000ish.

\subsection{Hypothesis}

Ha1: There is an influence of political marketing communication on Facebook towards the image of Joko Widodo among millennial generation

Ha2: There is an influence of political marketing communication on Facebook and the image of Joko Widodo towards reputation among millennial generation

Ha3: There is an influence of political marketing communication on Facebook and the image of Joko Widodo direct and indirectly towards Jokowi's reputation among millennial generation. 


\section{Research Method}

\subsection{Paradigm and Research Method}

This research used a positivist paradigm with a quantitative approach. The method used is a survey by distributing questionnaires as an instrument to collect data that aimed to obtain information from most millennials in Jakarta. This study uses several theories which are operationalized into three variables: Political Marketing Communication (Exogen) consist of Product Oriented Party, Sales Oriented Party, dan Market Oriented Party; Reputation (Endogen) consist of Emotional Appeal, Product and Service, Vision and Leadership, Work Environment Financial Performance, dan Social Responsibility; and Image (Intervening) consist of Perception, Cognition, Motivation, dan Attitude

The population in this research are millennials aged between 19-39 years old, participated in President General Election and legislative in 2019 and live in Jakarta. According to final voter lists (DPT) in general election 2019 which issued by General Election Commission Jakarta Province on 30th of August 2018, the number of voters aged between 19-39 years old is 2.885.000 people. Thus, the total population in this research is 2.885 .000 people. According to the Slovin formula, the number of samples taken are 400 people (rounded off). In this research, the authors will use data analysis techniques using path analysis,

\section{Results and Discussion}

a. Structure 1:

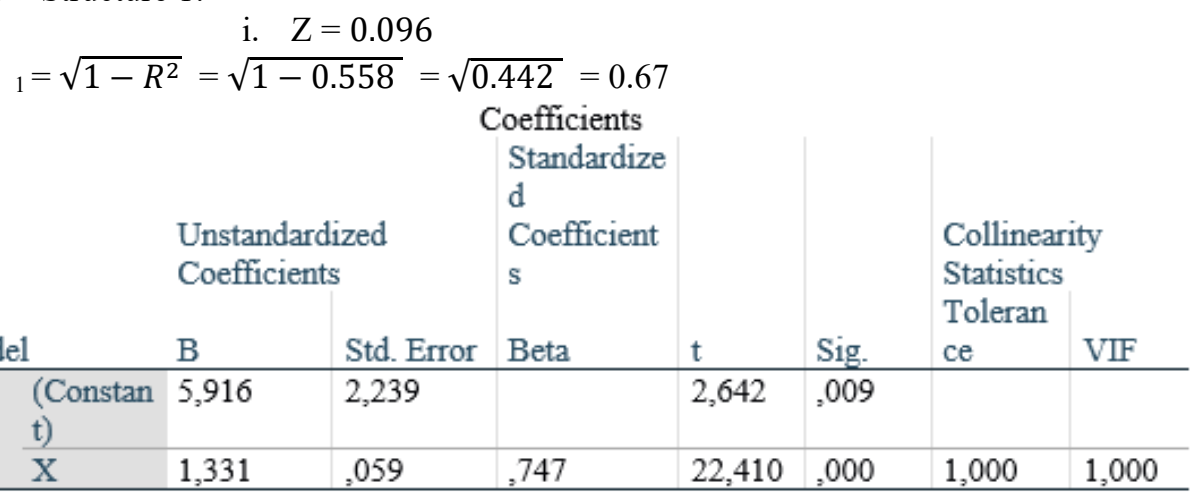

a. Dependent Variable: $\mathrm{Z}$

b. Structure 2:

- $\mathrm{Y}=0.747+0.866$

${ }_{1}=\sqrt{1-R^{2}}=\sqrt{1-0.883}=\sqrt{0.117}=0.34$

Coefficients

\begin{tabular}{|c|c|c|c|c|c|c|c|c|}
\hline \multirow[b]{2}{*}{ Model } & & \multicolumn{2}{|c|}{$\begin{array}{l}\text { Unstandardized } \\
\text { Coefficients }\end{array}$} & \multirow{2}{*}{$\begin{array}{l}\text { Standardized } \\
\text { Coefficients } \\
\text { Beta }\end{array}$} & \multirow[b]{2}{*}{$\mathrm{t}$} & \multirow[b]{2}{*}{ Sig. } & \multicolumn{2}{|c|}{$\begin{array}{l}\text { Collinearity } \\
\text { Statistics }\end{array}$} \\
\hline & & B & Std. Error & & & & Tolerance & VIF \\
\hline 1 & (Constant & $-11,339$ & 1,652 & & $-6,863$ & .000 & & \\
\hline & $\mathrm{x}$ & 244 &, 065 & 096 & 3,731 &, 000 &, 442 & 2,262 \\
\hline & $Z$ & 1,232 & 037 & 866 & 33,601 &, 000 & , 442 & 2,262 \\
\hline
\end{tabular}


c. Complete Structure:

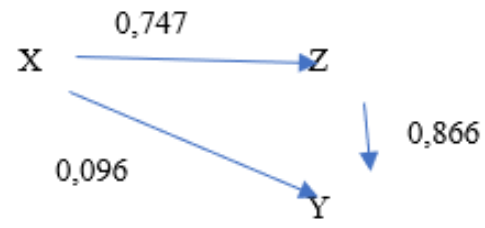

Based on path analysis test found out that:

- $\quad$ Path Model I - Influence X $\longrightarrow \mathrm{Z}$

Based on the test results for the effect of $X$ on $Z$, a significant value of 0.000 was found, which means that it is smaller than 0.05. It implies that Ha is accepted with its constant value of 1.331 , which means that it has a positive effect. The effect is 0.747 , or $74.7 \%$. It means that Joko Widodo's political marketing communications affect Joko Widodo's image by $74.7 \%$.

- $\quad$ Path Model II - Influence XZ $\longrightarrow$ Y

Based on the test results for the effect of $\mathrm{X}$ on $\mathrm{Y}$, a significant value of 0.000 was found, which means that it is smaller than 0.05. It implies that Ha is accepted with its constant value of 0,244 , which means that it has a positive effect. Based on the test results for the effect of $\mathrm{Z}$ on $\mathrm{Y}$, a significant value of 0.000 was found, which means that it is smaller than 0.05 . It implies that $\mathrm{Ha}$ is accepted with its constant value of 1,232 , which means that it has a positive effect. The magnitude of the influence of $\mathrm{X}$ and $\mathrm{Z}$ on $\mathrm{Y}$ is 0.883 or $88.3 \%$. It means that Joko Widodo's political marketing communications affect Joko Widodo's image by $88.3 \%$. Based on the results of the path analysis model II test, direct and indirect effects were found as follows:

\section{Direct Influence:} 0.866 .

The direct effect of variable $\mathrm{X}$ on $\mathrm{Y}$ is 0.096 , while the instant effect of variable $\mathrm{Z}$ on $\mathrm{Y}$ is

\section{Indirect Influence:}

The indirect effect of variable $\mathrm{X}$ through variable $\mathrm{Z}$ on variable $\mathrm{Y}$ is $0.747 \times 0.866=$ $0.6469=64.69 \%$. It means that the indirect effect of political marketing communication through the image variable on Joko Widodo's reputation is $64.69 \%$. The total influence given by variable $\mathrm{X}$ on $\mathrm{Y}$ is $0.096+0.6469=9.6 \%+64.69 \%=74.29 \%$. This means that the total influence exerted by political marketing communications on Joko Widodo's reputation is $74.29 \%$.

\section{Conclusions}

Based on the data analysis result carried out in this research. Therefore there are three conclusions we can deliver; those are: Political marketing communication conducted on Facebook has a positive and significant impact on Joko Widodo's image among the millennial generation; Political marketing communication conducted on Facebook has a positive and significant effect on Joko Widodo's reputation among the millennial generation; Political marketing communication conducted on Facebook and the image of Joko Widodo, directly and indirectly, affect Jokowi's reputation among the millennial generation. 
The result of this research shows that the direct influence of political marketing communication on Facebook is only $11.2 \%$ in affecting Joko Widodo's reputation. Thus, attempts to deliver political messages as a form of political marketing communication carried out by Joko Widodo in social media, particularly in Facebook, must be improved.

\section{References}

[1] M. P. Firmanzah, “Antara Pemahaman dan Realitas,” Jakarta Yayasan Obor Indones., 2012.

[2] E. Y. Okan, A. Topcu, and S. Akyüz, "The role of social media in political marketing: 2014 local elections of turkey,” Eur. J. Bus. Manag., vol. 6, no. 22, pp. 131-140, 2014.

[3] E. Murwani, "The Impression Management Strategy of the Candidates of Governor-Vice Governor of DKI Jakarta on Social Media,” J. Komun. Ikat. Sarj. Komun. Indones., vol. 3, no. 2, pp. 113-121, 2018.

[4] A. A. Unde and others, "The Internet and Social Media in Political Participation in Indonesia," 2016.

[5] M. J. Jensen, "Social media and political campaigning: Changing terms of engagement?," Int. J. Press., vol. 22, no. 1, pp. 23-42, 2017.

[6] Z. M. Monggilo, "Kajian Literatur Tentang Tipologi Perilaku Berinternet Generasi Muda Indonesia," 2016.

[7] M. S. Saraswati, "Social media and the political campaign industry in Indonesia," J. Komun. Ikat. Sarj. Komun. Indones., vol. 3, no. 1, pp. 51-65, 2018.

[8] D. Fadillah, L. Z. Lin, and D. Hao, "Social Media and General Elections in Malaysia 2018 and Indonesia 2019,” J. Komun. Ikat. Sarj. Komun. Indones., vol. 4, no. 1, pp. 1-8, 2019.

[9] D. Sahputra, I. Muda, T. W. Hidayat, and W. Waridah, "Social Media and Civil Society in the Governor's Election of North Sumatera 2018,” J. Komun. Ikat. Sarj. Komun. Indones., vol. 5, no. 1 , pp. $10-17,2020$.

[10] D. Holmes and others, "Understanding the Indonesian mediapolis: The role of social media during the 2014 Indonesian presidential election," Commun. Polit. Cult., vol. 49, no. 2, p. 50, 2016.

[11] N. Kholisoh, E. Yuliawati, N. R. Suci, and T. Suharman, "The Influence of Political Messages in New Media to Political Awareness and Its Impact on the Political Participation of Millennial Generation,” J. Komun. Ikat. Sarj. Komun. Indones., vol. 4, no. 2, pp. 128-139, 2019.

[12] E. Maryani, D. Rahmawan, I. Garnesia, and R. A. Ratmita, "Management and Psychological Aspect: Teenagers' Awareness of Privacy in Social Media," J. Komun. Ikat. Sarj. Komun. Indones., vol. 5, no. 2, 2020.

[13] O. U. Effendy, Ilmu komunikasi teori dan praktek. Remaja Rosdakarya, 1990.

[14] J. Lees-Marshment, B. Conley, and K. Cosgrove, Political marketing in the United States. Routledge, 2014.

[15] F. Sulianta, Keajaiban sosial media. Elex Media Komputindo, 2015.

[16] H. Allcott and M. Gentzkow, "Social media and fake news in the 2016 election," J. Econ. Perspect., vol. 31, no. 2, pp. 211-236, 2017.

[17] R. Hájek, "Politicising Platform, or Another Campaign Tool: Locality-Related Differences in the Perception of Facebook s Role in Pre-Election Period," Obs., vol. 12, no. 3, pp. 1-16, 2018.

[18] R. S. Fajrina, "Pengaruh Reputasi Perusahaan Dan Komunikasi Word-Of--Mouth Terhadap Pembuatan Keputusan Melamar Kerja," J. Manaj. Komun. Kekhususan Manaj. Korporasi, 2012.

[19] V. Jain, M. Chawla, B. E. Ganesh, and C. Pich, "Exploring and consolidating the brand personality elements of the political leader," Spanish J. Mark., 2018.

[20] Y. Zalpha, “Analisis Konflik pada Munas Golkar 2014,” Intizar, vol. 22, no. 1, pp. 155-172, 2016. 
[21] B. R. Kupperschmidt, "Multigeneration employees: Strategies for effective management," Health Care Manag. (Frederick)., vol. 19, no. 1, pp. 65-76, 2000.

[22] N. Howe and W. Strauss, Generations: The history of America's future, 1584 to 2069. Harper Collins, 1992.

[23] N. Howe and W. Strauss, Millennials rising: The next great generation. Vintage, 2000. 